\section{The Almond in Morocco}

\author{
Ahmed Mahhou ${ }^{1}$ and \\ Frank G. Dennis, Jr. ${ }^{2}$
}

Additional index words. production methods, marketing, research, cultivar selection, germplasm preservation

Summary. Morocco ranks fifth among the nations of the world in almond (Prunus dulcis L.) production, and contains many zones where climatic conditions are ideal for this species. Seedling trees are responsible for more than half the total production, although grafted trees are usually much more productive per hectare. A large seedling population represents an important gene pool, both for a breeding program and for selection of superior genotypes adapted to Moroccan conditions.

W orld almond production is concentrated in three regions: a) Asia, b) the Mediterranean basin, and c) California, with limited amounts in Australia, South Africa, Chile, and Argentina. In Asia and North Africa, almond-growing practices have changed little during recent centuries. Many orchards consist of seedlings; when grown in mixed cultures with other crops under minimal care, yields are low.

California s 166,000 ha of bearing trees account for $-70 \%$ of the world s almond production. Sixty percent to $70 \%$ of California s production is exported to $>40$ countries. Spain is the second-most important producing country, with $15 \%$ to $20 \%$ of the world s total production grown on $\approx 567,000$ ha. Other countries contributing to the world total include Italy (5\%), Greece (5\%), Morocco $(2 \%)$, and Portugal ( $1 \%$ ) .

The almond originated in the mountainous regions of Iran, Afghanistan, and the former Soviet Union (Grasselly and Crossa-Raynaud, 1980).

${ }^{1}$ Associate Professor, Departement d' Horticulture, Institut Agronomique et Vétérinaire Hassan II, B.P. 6202, Rabat, Morocco.

${ }^{2}$ Professor, Department of Horticulture, Michigan State University, East Lansing, MI 48824-1325.
Almond is primarily limited in its geographical adaptation by its susceptibility to spring frost. This hazard arises directly from early flowering and leafing. Where frost is not a problem, major yield limitations are rain and cool temperature during bloom, which interfere with cross-pollination and promote fungal diseases of leaves and flowers. Conditions favorable for almond culture include 100 to $400 \mathrm{~h}$ of chilling at temperatures below $7.2 \mathrm{C}$ (Tabuenca, 1972), limited danger of spring frost injury, and a warm, dry climate to avoid fungal infection. The trees can perform fairly well even with moderate care. They exhibit greater resistance to drought than other stone fruits, and are able to grow in calcareous soils. Fruits have no fleshy pericarp requiring special handling, and the edible seeds can be stored dry without refrigeration for a time. These characteristics make almond a good crop for owners of small farms in developing countries.

We present here an overview of almond production and research in Morocco-the fifth-largest producer ofalmonds $(9,000-12,000 \mathrm{t}$ ofshelled almonds per year) (Direction de le Planification et des Affaires Economiques, 1987), after the United States $(264,000 \mathrm{t})$, Spain $(73,000 \mathrm{t})$, Greece $(17,000 \mathrm{t})$, and Italy $(16,000 \mathrm{t})$ (Grasselly and Souty, 1988).

\section{Acreage and production}

Morocco has a mild, Mediterranean climate with areas well-suited to almond growing (see Fig. 1 for areas mentioned). In terms of surface area occupied by tree fruits in 1987-88, almonds $(95,000$ ha) were second only to olives $(337,000$ ha) (Division de 1 Horticulture, 1987-88). Additional plantings by governmental agencies increased total acreage to 104,000 ha in 1988-89 (Division de 1 Horticulture, 1988-89). Almonds are grown under two types of culture that can be described broadly as a) traditional and b) semi-intensive (Lousert et al., 1989).

Traditional culture. Almonds are grown under conditions where one or more environmental requirements are limiting. These include water during the growing season, soil depth, and nutrients, primarily N. Trees (mostly open-pollinated seedlings) are planted on slopes and hillsides, along streams, or interplanted with field crops, and 


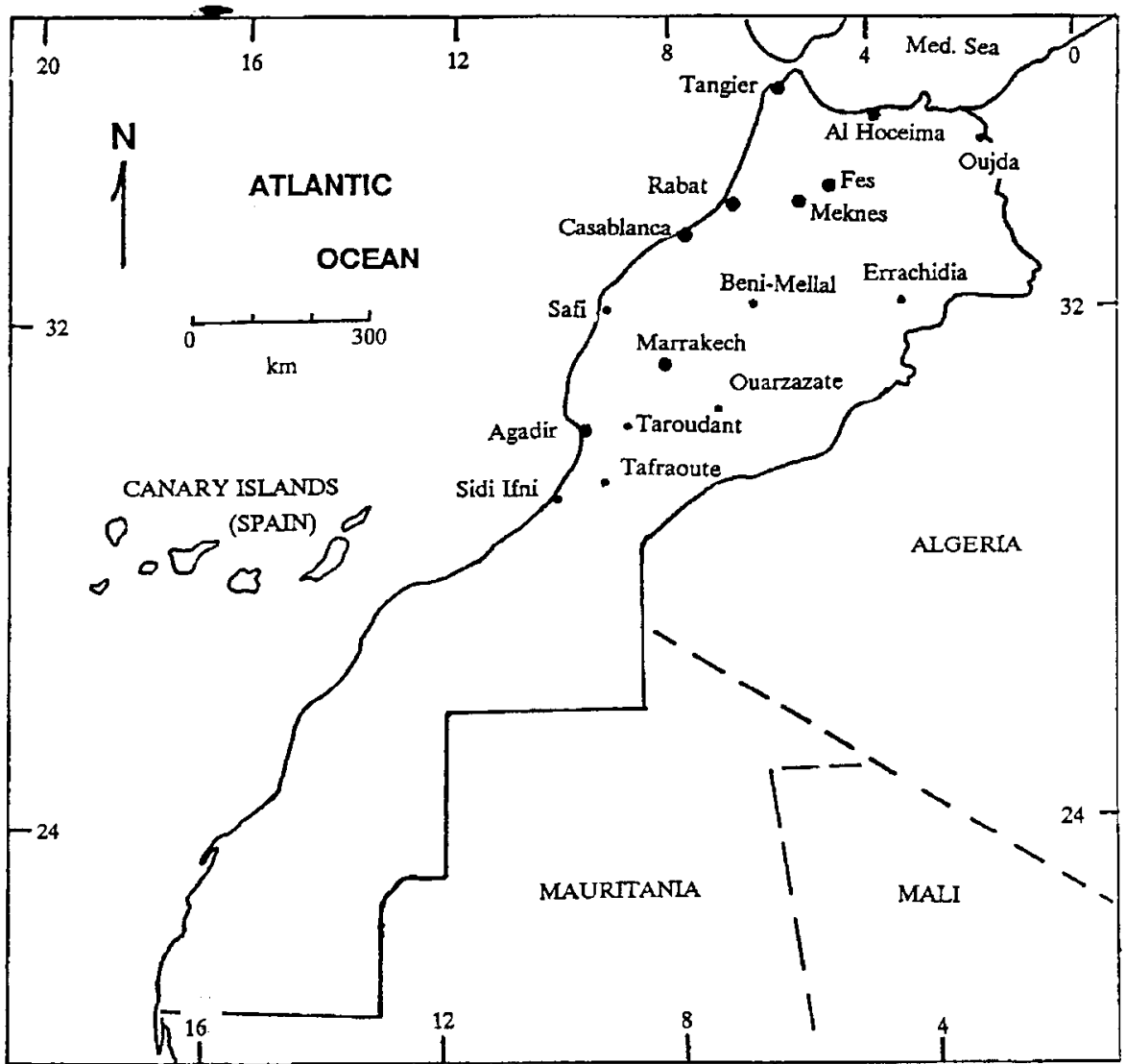

Fig. 1. Map of Morocco, with cities and villages mentioned in the text.

are given little or no care (Fig. 2A). This sector covers more than 70,000 ha and represents $70 \%$ to $80 \%$ of the almond plantings in Morocco $(8 \mathrm{mil}-$ lion trees). The trees are planted at an average density of 80 trees/ha. The Service of Forestry and Water (Service des Eaux et Forêts) has planted 5 million trees, mostly Marcona, on contours as part of its soil conservation mission Defense et Restauration des Sols (DRS) (Laghezali, 1985). These trees are neither pruned nor sprayed, but are harvested by local farmers. The almonds are used by the family or sold locally.

Despite their low productivity, seedling trees represent a potential source ofgermplasm, both for selection of new cultivars and for use as parents in breeding programs (see below). Many microclimates exist, and result in considerable variation among seedling populations. Many of the local plantings have evolved through natural and human selection and represent distinct ecotypes or landraces. Much of the population has moved from rural to urban areas, and many people work in Europe for much of the year.
This has further limited the care that seedling populations receive. Lack of care, togetherwith severe drought conditions during the early 1980s, continues to threaten the continued existence of many of these trees.

Sixty-five percent of the almond crop is produced on small farms in the traditional sector. Yields are low under this cultural system and trees show a strong tendency toward alternate bearing. The causes of low yield include: a) marginal and poor soils; b) low rainfall, resulting in moisture stress and reduced flower bud initiation; c) spring frosts; d) rain and cool temperatures during bloom, which restrict cross-pollination and favor fungal diseases; e) lack or absence of pollinizers; f) limited care and management; and g) lack of vigor. Low yields despite heavy blooms suggest that pollination is one of the most limiting factors for the performance of almond in this system. Most almond cultivars are self-incompatible. In addition, they require pollen transfer by insects, primarily honeybees, for crosspollination. Some growers have topgrafted named cultivars on the scaffold limbs of seedlings. In the area near $\mathrm{Al}$
Hoceima, on the Mediterranean, 46\% of an estimated 17,500 trees were grafted in 1989 (Service de la Mise en Valeur Agricole, n.d.).

Semi-intensive culture. In this system, trees are planted at 150 to 300/ ha (Loussert et al., 1989) on a total of 34,000 ha. Most trees are grafted and the cultivars are chosen based on their performance, overlapping bloom, and compatibility for cross-pollination. Most of these trees are located in commercial zones where irrigation is possible (Fig. 2B). Few of these orchards are actually irrigated, however, for other rosaceous fruits (apples, pears, peaches, prunes) have priority for water. The most-important cultivars are Marcona and Fournat de Brezenaud (Loussert et al., 1989). Other cultivars include Desmayo Largueta, $\mathrm{Ne}(\mathrm{c})$ Plus Ultra, Abiod, and $\mathrm{Ai}$. None of these cultivars is of Moroccan origin. Because of the danger of frost injury, several of the new, late-blooming French cultivars, including Ferragnès and Ferraduel, are of considerable interest. Aside from a small number of peach-almond hybrids, seedlings of Marcona are generally used as rootstocks. Almond seedlings are outstanding for their deep rooting ability and tolerance to drought and calcareous soils. Growers often plant seeds on site, then graft scions of known cultivars on the seedlings. This allows the taproot to continue developing, thus providing greater drought resistance than is the case with trees that are transplanted from a nursery.

Area planted in the commercial sector declined from 50,300 ha in 1969 to 34,600 ha in 1985 (Direction de la Planification et des Affaires Economiques, 1985). Among the reasons for this decline are: a) a shift to other deciduous tree fruits, including apple, peach, pear, plum, apricot (total increase of 31,800 ha during the same period), and olives (increase of 67,000 ha); b) a series of dry years from 1980 to 1984 ; c) attack by insects, particularly a bark beetle [Scolytus (Ruguloscolytus) amygdali], and capnode (Capnodis tenebrionis L.) that attacks the roots (Loussert et al., 1989); and d) low returns in comparison with competitive crops, especially wheat. (The price of wheat is subsidized and its production involves no lag period ofseveral years prior to cropping. ) However, the decline in acreage was offset by an increase in mean yield 

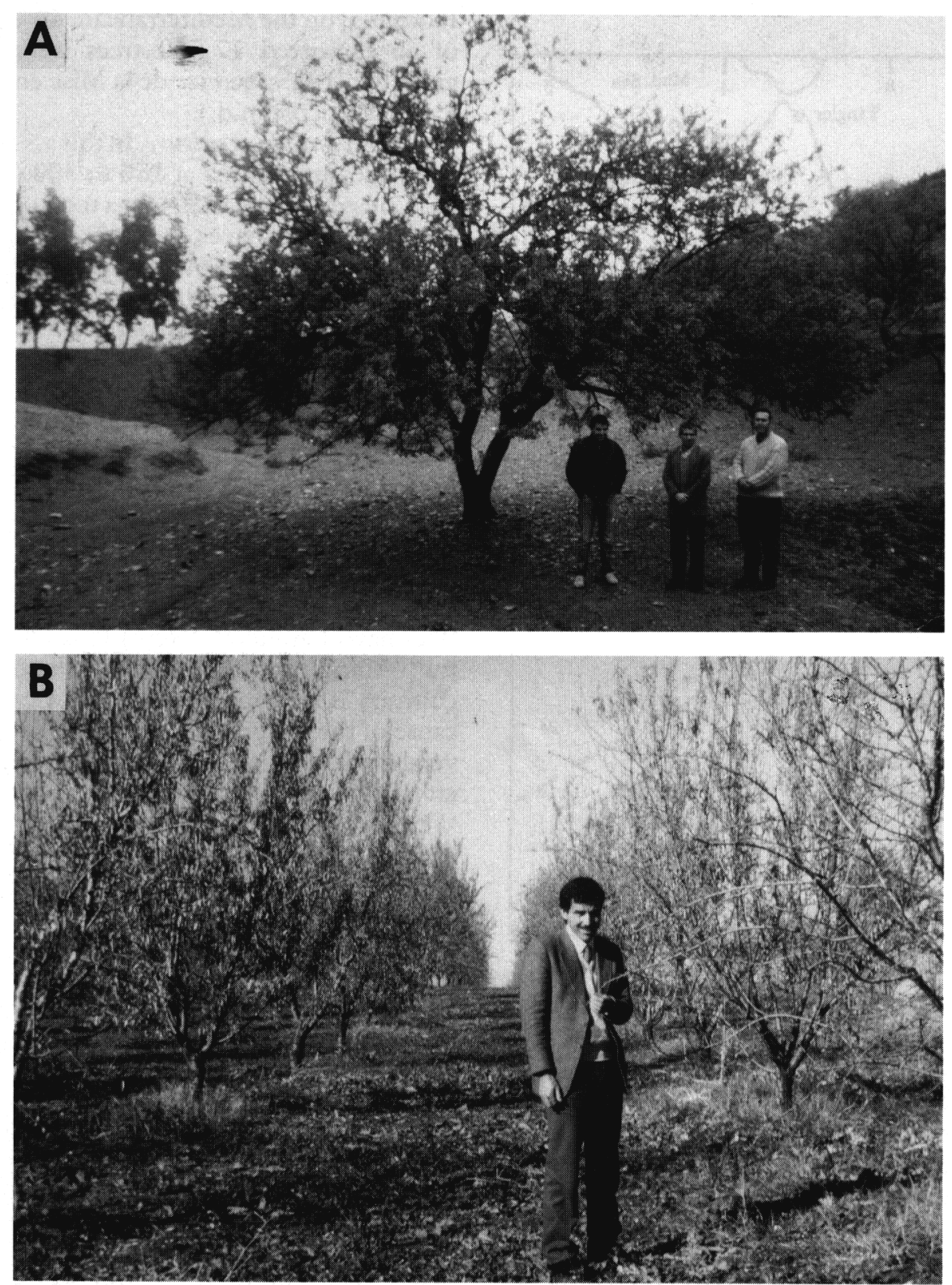

Fig. 2. Traditional seedling almond tree near Al-Hoceima (A) and semi-intensivegrafted trees near Meknès (B).

from 190 to $300 \mathrm{~kg}$ of shelled almonds per hectare (Loussert et al., 1989). Closer planting, introduction of moreproductive cultivars, and better cultural practices were responsible for this increase (Loussert et al., 1989). Nevertheless, yields remain low relative to those of California. Yields of 2200 to $3300 \mathrm{~kg}$ of shelled almonds/ha can be obtained in well-managed, irrigated California orchards under the intensive culture system of management, and yields as high as $4480 \mathrm{~kg} \mathrm{ha}^{-1}$ have been reported (Rough et al., 1989). Without irrigation, the yield in Morocco varied from 30 (Al Hoceima) to 3700 (Errachidia) $\mathrm{kg} \mathrm{ha}^{-1}$ in shell (about 10 to 1200 shelled) in 1988-89 (Division del Horticulture, 1988-89). The high- very popular in Morocco, being used in main dishes. as hors d oeuvres, and in baked goods and almond pastes. Some of the best-quality almonds are candied to form the popular dragées.

\section{Research}

Horticultural research, teaching, and extension are developed after the French rather than the United States model, with separate institutions. There are three organizations that are involved with horticultural research, extension, and teaching.

The Institut National de la Recherche Agronomique (INRA) has primary responsibility for research in all areas of agriculture. Extension is conducted by the Direction de Vulgarisation et de la Reforme Agraire (DVRA), Ministère de 1 Agriculture. DVRA is represented at the local level by the Directions Provinciales d Agriculture (DPA) and the Offices Régionaux de Mise en Valeur Agricole (ORMVA) in irrigated zones.

University-level education in horticulture is carried out by the Institut Agronomique et Vétéinaire Hassan II (I.A.V.), the main campus of which is located at Rabat. Horticultural programs are presently divided among three locations: Rabat, Agadir, and Meknès. The university is also involved in research in connection with undergraduate and MS theses and PhD programs, most of which are carried out in conjunction with foreign universities, particularly the United States, through the USAID/Minnesota Project.

Several INRA research stations, including those at Ain Taoujdate (near Meknes), at Marrakech, and at Errachidia, conduct cultivar testing and/ or evaluation of local almond genotypes. Laghezali and Oufkir (1989) evaluated a total of 60 European, American, and local cultivars planted at Ain Taoujdate for fruit and seed characteristics, tree form, bloom and harvest dates, and tolerance to diseases. No data have been published on yield, however.

The abundance of almond seedlings and their wide distribution provide good possibilities for selecting superior genotypes. Because the species is highly self-sterile and heterozygous; wide genetic variability is evident within the population. However, relatively little research has been devoted to selection of clones. Barbeau and El Bouami $(1979,1980)$ of INRA, Marrakech, 

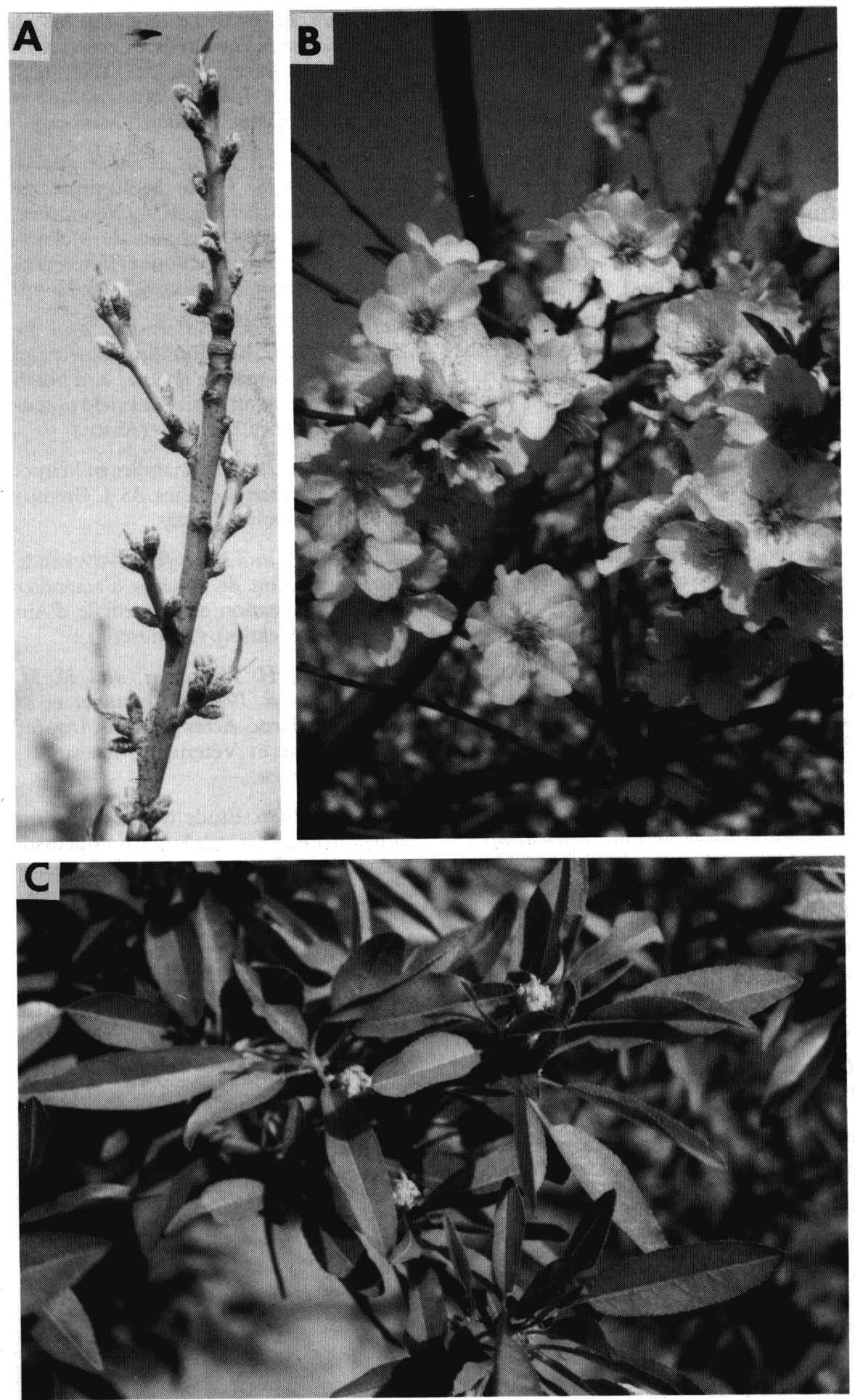

Fig. 3. Representative examples indicáting the range in stage of development of trees in the collection at Marrakech on 22 Feb. 1990. Trees were propagated by grafting selected seedlings on $<$ Marcona $>$ rootstocks.

marked 200 seedlings for evaluation in Ouarzazate and Errachidia provinces in southern Morocco in the mid- 1970s and recorded eight characteristics of economic value for 3 consecutive years. Fifty-three seedlings with useful characteristics for breeding purposes were propagated for further evaluation at both Errachidia and Marrakech (Fig.
3). Seedlings of Marcona were used as a rootstock, and two commercial cultivars (Ferragnès and Tardy Nonpareil ) and a self-fertile Italian cultivar ( Tuono ), were included for comparison. Over a 4-year period, five of the clones yielded more than $5 \mathrm{~kg}$ of almonds, in shell, per tree annually at Marrakech, and 19 produced more than 3 kg, whereas Ferragnès, Tuono, and Tardy Non-Pareil produced only $1.5,1.0$, and $0 \mathrm{~kg}$, respectively (Mouhri, 1986). (Possible climatic $\times$ cultivar interactions are suggested by the observation that Tuono has produced well when planted in a Solid block at Ain Taoujdate.) Laghezali (1985) evaluated 16 clones selected in seedling orchards in northern (Al Hoceima) and southern (Tafraoute) Morocco. These were classified according to eight characteristics, including both tree and nut properties. Chahbar (unpublished data) made a similar study in the $\mathrm{Al}$ Hoceima area over a 2-year period. However, in neither case were clones propagated for further evaluation. A small collection of genotypes from the area near Taroudant exists at the INR4 station at Oulad Berhill, 60 miles south of Agadir. However, no data are available as to performance of these genotypes at this time (Hamon, personal communication).

Neumann (unpublished data), workingwith the German technical assistance program (GTZ) at Al Hoceima, collected several clones for possible use as rootstocks. These clones are included in a budwood block at Ain Taoujdate, but no data are known to exist as to their effects upon scion performance.

Benazoun (1984) of the I.A.V., Agadir, conducted an extensive study of the life cycle of the almond bark beetle in intercropped orchards in the area near Beni-Mellal and Tafiaoute. Although some natural predators were found, none was effective in controlling the insect. A single spray of deltamethrin [(S)- $\alpha$-cyano-3-phenoxybenzyl(1R,3R)-3-(2,2-dibromovinyl-2,2dimethyl-cyclopropanecarboxylate)] was partially effective, however, when applied during spring emergence of adults (Benazoun and Schvester, 1989). Farmers in this area are reluctant to spray trees during the growing season for fear of mechanical damage to the crops grown between them (A. Benazoun, personal communication).

Capnode (Capnodis tenebrionis L.) became a serious threat to all stone fruits during the drought years of the early 1980s. The larvae of this beetle attack the roots and crowns of trees that have been weakened by drought or disease. Young trees that have not been well-cared for are particularly susceptible. Hmimina (1989) and Hmimina et al. (1988) have described the 
life cycle of this insect. Once eggs have been laid, control is very difficult, as the larvae are subterranean. $\mathrm{HCH}$ (mixed isomers of 1,2,3,4,5,6-hexachlorocyclohexane) applied to the soil during the oviposition period was the only treatment found to be effective. Although $\mathrm{HCH}$ has now been banned, ethyl chloropyrophosphate is being evaluated (Loussert et al, 1989).

\section{Research priorities}

Despite a high demand for almonds on the domestic market, the profit margin is often narrow, and greater efficiency is essential. A major factor limiting yield is water. Irrigation alone would greatly increase production, were it available.

As noted above, biennial bearing is a problem. This may be associated with certain cultivars, or with weather conditions during bloom, and may be intensified by moisture stress from lack of fall rains. Some research is needed to establish the reasons for this tendency and to determine how to correct it. In France, heavy fruiting limits flower initiation in certain cultivars (e.g., Rachele ) but not in others (e.g., Ferragnès, Nonpareil) (Grasselly and Crossa-Raynaud, 1980).

Production efficiency could also be improved by selecting superior clones from the large seedling population. Establishment of a germplasm bank would preserve clones that may have valuable scion and/or rootstock characteristics, such as drought tolerance, but lack the full range ofqualities necessary for commercial production. These should be propagated and evaluated at several locations because of the great difference in chilling hours, precipitation, and soil types that occur among almond-growing areas. Late bloom to avoid frosts is of high priority. Self-fertility should also be evaluated, as none of the cultivars currently grown commercially is self-fertile. This seedling population might also provide superior rootstocks. A breeding program may be initiated at the Ecole Na-tionale d Agriculture (ENA) at Meknès. Seedling selections could provide some useful germplasm for this program.

\section{Literature Cited}

Barbeau, G. and A. El Bouami. 1979. Prospections de tardiveté de floraison chez 1 amandier dans le Sud Marocain. Fruits 34(2):131-137.

Barbeau, G. and A. El Bouami. 1980. Prospections Amandiers dans le Sud Marocain. Fruits 35(1):39-49.

Benazoun, A. 1984. Contribution à 1 étude bio-écologique du Scolyte de 1 Amandier: Scolytus (Ruguloscolytus) amygdali (Guerin) au Maroc. PhD Diss., Univ. of Paris VI

Benazoun, A. and D. Schvester. 1989. Essai de traitement chimique à la deltamethrine sur Amandier contre Scolytus (Ruguloscolytus) amygdali (Guer.). Actes, Institut Agronomique et Vétérinaire Hassan II, Rabat, Morocco 9(1):25-30.

Direction de la Planification et des Affaires Economiques, Ministere de l Agriculture et de la Reforme Agraire. 1987. Superficie et rendements des productions agricoles de 1969 à 1985.

Division de l'Horticulture, Direction de la Production Végétale, Ministère de $1 \mathrm{Ag}$ riculture et de la Réforme Agraire. Bilan de la campagne agricole 1987-88.

Division de L Horticulture, Direction de la Production Végétale, Ministère de 1 Agriculture et de la Réforme Agraire. 1990. Bilan de la production d amandier, campagne 1988-89.

Grasselly, C. and R. Crossa-Raynaud. 1980. L Amandier. Maisonneuve et Larose, Paris.

Grasselly, C. and B. Souty. 1988. La culture de 1 amandier en France. L Arboriculture Fruitière 402:21-24.
Hmimina, M. 1989. Le capnode. In: M. Hmimina and A. Fraval (eds. ). Les ravageurs des arbres fruitiers, Doc. Sci. Tech. n 5 , Actes Editions, Institut Agronomique et Vétérinaire Hassan II, Rabat, Morocco.

Hmimina, M., A. Sekkat, L. Lahfa, and M. Histane. 1988. Cycle biologique de Capnodis tenebrionis L. (Coleoptera, Buprestidae) dans la region de Meknès. Actes, Institut Agronomique et Vétérinaire Hassan II, Rabat, Morocco 8(1-2):41-49.

Kester, D.E., K. Pelletreau, and D. Zivorofsky. 1987. Relationship of flower and distribution in mature almond and peach cultivars to fruiting habits and yield potential. HortScience 22:1093. (Abstr.)

Laghezali, M. 1985. L amandier au Maroc. Options Mediterraneènnes. 85-I, Grempa Colloqium, Izmir, Turkey.

Laghezali, M., and M. Oufkir. 1989. Etude $\mathrm{d}$ une collection de variétés $\mathrm{d}$ amandier installée à la station expérimentale d Ain Taoujdate (Meknes). (Manuscript).

Loussert, R., H. Moussaoui, and D. M. Walali Loudiyi. 1989. L Amandier et sa culture au Maroc. Actes Editions, Institut Agronomique et Vétérinaire Hassan II, Rabat, Morocco.

Mouhri, J. 1986. Etude d une collection clonale $\mathrm{d}$ amandier et de la non productivité des clones à floraison tardive à MenaraMarrakech. Thesis for Ingénieur Horticole, Institut Agronomique et Vétérinaire Hassan II, Rabat, Morocco.

Rough, D., P.S. Verdegaal, and T. Viss. 1989. Evaluation and selection of current almond varieties. Coop. Ext., Univ. of California, Coop. Ext, San Joaquin Co., Calif.

Tabuenca, M. C. 1972. Necesidades de frio invernal en almendro. Anales de la Estacion Experimental de Aula Dei. 11:325-329.

Service de La Mise en Valeur Agricole, Direction Provinciale d Agriculture d Al Hoceima, Ministère de 1 Agriculture et de la Réforme Agraire. 